\title{
Virulence factors of Escherichia coli in relation to the importance of vaccination in pigs
}

\author{
Fatores de virulência da Escherichia coli associados à importância da vacinação nos suínos
}

\author{
Daniele Araujo PereiraI ${ }^{I}$ Marilda Carlos Vidotto ${ }^{I I}$ Karla Alvarenga Nascimento \\ Anne Caroline Ramos dos Santos ${ }^{\mathrm{I}}$ Marina Lopes Mechler ${ }^{\mathrm{III}}$ Luís Guilherme de Oliveira ${ }^{\mathrm{I}}$
}

\section{- REVIEW -}

\section{ABSTRACT}

Enterotoxigenic Escherichia coli (ETEC) is the major cause of diarrhea in newborn and weaned pigs. Bacteria adhesion to the host cell is considered a specific phenomenon among fimbrial and non-fimbrial adhesins with their respective receptors on enterocytes. Enteric disorders are related with the fimbriae F4 (K88), F5 (K99), F6 (987P), F41, and F18. In addition to ETEC, another category of $\boldsymbol{E}$. coli, porcine pathogenic E. coli (PEPEC), can cause diarrhea in pigs; it produces the porcine attaching and effacing-associated (Paa) adhesin in which is capable to cause a typical lesion known as an attaching and effacing $(A / E)$ lesion. Immunization of sows with adhesin is important to stimulate the production of antibodies and their subsequent transfer to piglets through colostrum. The aim of this paper is to illustrate the main impacts of enteric diseases caused by $\boldsymbol{E}$. coli in swine production and to highlight the importance of continuing research on this bacterium to improve disease prevention through vaccination.

Key words: colibacillosis, diarrhea, vaccines, swine, colostrum RESUMO

Escherichia coli (E. coli) enterotoxigenica (ETEC) é considerada importante causa de diarreia em suínos neonatos e desmamados. A adesão da bactéria à célula do hospedeiro é considerada um fenomeno especifico entre as adesinas fimbriais e não fimbriais com seus respectivos receptores nos enterócitos. Os distúrbios entéricos estão relacionados com as fimbrias $\mathrm{F} 4$ (K88), F5 (K99), F6 (987P), F41 e F18. Além da ETEC, outra categoria de $\boldsymbol{E}$. coli pode causar diarreia nos suinos, denominada de PEPEC (porcine pathogenic $\boldsymbol{E}$. coli), a qual produz a adesina Paa (Porcine attaching adherence), capaz de provocar uma lesão típica denominada $A / E$ (attaching and effacing). A imunização das matrizes com adesinas é importante para estimular a produção de anticorpos e a consequente transferência através do colostro aos leitões. $O$ objetivo deste trabalho foi mostrar os principais impactos das doenças entéricas causadas por Escherichia coli na produção de suínos, e mostrar a importância de atualizar o estudo dessa bactéria para prevenir a doença através da vacinação.

Palavras-chave: colibacilose, diarreia, vacinas, suínos, colostro.

\section{INTRODUCTION}

Enteric diseases of bacterial etiology, particularly those caused by Escherichia coli, are the major concern in pig farming and have a heavy impact on pork industry (MENIN et al., 2008). Therefore, to avoid losses in pig farming, care during the initial disease phase is essential through a quick and accurate enteric diagnosis associated with a full history, clinical signs, and pathology. Recent advances in diagnostic methods have enabled a better understanding of diseases and have helped to reduce the effects in swine (WILLS, 2000).

The main cause of economic losses in young pigs is related to enteritis because it causes diarrhea, decreased weight loss in food conversion, culling, and sudden death. The diarrheal syndrome is responsible for $6 \%$ of piglets mortality on farms (CARAMORI JÚNIOR et al., 2010). Among the agents that cause

\footnotetext{
"Departamento de Clínica e Cirurgia Veterinária, Universidade Estadual Paulista "Júlio de Mesquita Filho" (UNESP), Via de Acesso Prof. Paulo Donato Castellane, s/n., 14884-900, Jaboticabal, SP, Brasil. E-mail: luis.guilherme@fcav.unesp.br. "Corresponding author.

"Departamento de Medicina Veterinária Preventiva, Universidade Estadual de Londrina (UEL), Campus Universitário Centro de Ciências Agrárias, Londrina, PR, Brasil.

IIIDepartamento de Medicina Veterinária, Universidade Federal de Lavras (UFLA), Lavras, MG, Brasil. 
diarrhea in suckling piglets are Isospora suis, coronavirus, rotavirus, and Clostridium perfringens type C, although enterotoxigenic $\boldsymbol{E}$. coli (ETEC) can be considered the most important agent capable of causing illness and death in newborn and weaned piglets (ALMEIDA et al., 2007). Colibacillosis may have a mortality rate of approximately $25 \%$ if measures such as prevention and treatment are not adopted (MORÉS \& MORENO, 2007).

\section{Etiology}

E. coli is a facultative anaerobic bacterium belonging to the family Enterobacteriaceae; it is a Gram-negative rod, non-sporulating, and either nonmobile or moved by peritrichous flagella (HIRSH et al., 2003). These bacteria have the ability to reduce nitrate to nitrite and to ferment glucose. They also are oxidase- negative and metabolize a wide variety of substances such as carbohydrates, proteins, amino acids, lipids, and organic acids. They produce catalase and glucose and use ammonia as the only source of carbon and nitrogen (TRABULSI \& ALTERTHUM, 2005).

Although $\boldsymbol{E}$. coli bacteria are part of the normal flora of human and other animal species intestinal tracts, a few strains are pathogenic due to specific features. These can be classified into six groups: enteropathogenic $\boldsymbol{E}$. coli (EPEC), enterohemorrhagic E. coli (EHEC), enterotoxigenic E. coli (ETEC), entero aggregative $\boldsymbol{E}$. coli (EAEC), entero invasive $\boldsymbol{E}$. coli (EIEC), and diffusely adherent $\boldsymbol{E}$. coli (DAEC) (TRABULSI et al.,2002). Among these, the bacteria belonging to the ETEC group are primarily responsible for colibacillosis in both newborn and weaned pigs (MELKEBEEK et al., 2013).

Serological classification of $\boldsymbol{E}$. coli is based on the four surface antigens: $\mathrm{O}$ (somatic antigen), $\mathrm{k}$ (capsular antigen), $\mathrm{H}$ (flagellar antigen), and F (fimbrial antigen) (ORSKOV et al., 1977). ETEC strains that cause diarrhea in pigs have two fundamental factors of virulence, the adhesins and enterotoxins (MOON $\&$ BUNN, 1993). These may be expressed by several genes located on different segments of chromosomes and/or plasmids, and they are differentiated by their hemagglutinating, serological, and morphological properties. The majority of the protein subunits of the fimbriae are attached to the erythrocytes' integrated sugars, causing hemagglutination in the presence of D-mannose (BLANCO et al., 1993).

The ETEC found in pigs have shown several adhesin in types, defined as fimbriae F4, F5, F6, F18, and F41 (VIDOTTO et al., 2009;LIU et al., 2014). The expression of these fimbriae is stimulated in vitro by growth conditions such as $\mathrm{pH}$, rearing temperature, aeration, and osmolarity of the medium, with a specific medium for each fimbria (GAASTRA \& GRAAF, 1982).

Pathogenesis associated with the bacterial virulence factors

Colibacillosis begins when there is binding of the bacteria to specific receptors of enterocytes through the fimbrial adhesins. Toxins are then released to activate the production of the enzymes adenylate cyclase and guanylyl cyclase, which increases the intracellular concentration of cyclic adenosine monophosphate (cAMP), generating a greater transfer of sodium bicarbonate and water from the gut lumen cells (MORÉS \& MORENO, 2007). Colibacillosis, when caused by ETEC toxins, causes dehydration leading to animal death by secretory diarrhea, with fluid excretion higher than the absorption capacity generating a dysfunction of the physiological processes (ZLOTOWSKI et al., 2008).

The enterotoxins are classified into thermo stable (STa and $\mathrm{STb}$ ) and thermo labile (LT-1 and LT-2); these are responsible for causing imbalances in the absorption and secretion of electrolytes and water by the enterocytes, leading to diarrhea, dehydration, and death of animals (MORÉS \& MORENO, 2007). ETEC is able to produce several protein toxins that differ in weight, molecular structure, and biological and immunological activity (GYLES et al., 1992).

The K88 fimbria, also currently known as F4, was the first studied after it was discovered in 1961 by serological testing from pigs with edema disease and enteritis (ORSKOV et al., 1961); its antigenic variants were differentiated into K88ab, K88ac, and K88ad (FAIRBROTHER et al., 2005), with the K88ac variant being most commonly reported in piglets with diarrhea. This fimbria is characterized by a diameter of $2.1 \mathrm{~nm}$ and molecular weight of 27.5 kilodalton $(\mathrm{kDa})$. The specific culture medium for expression of F4 is agar glucose, and this fimbria enables $\boldsymbol{E}$. coli to hemagglutinate guinea pig erythrocytes in the presence of mannose (MOON, 1983).

RUTTER \& JONES (1973) tested the first F4 vaccine in sows to protect the newborn piglets with passive immunity via colostrum. An F4 vaccine was able to protect piglets that received antibodies through colostrum during weaning (NAGY \& FEKETE, 1999). A study conducted with samples from a diarrhea outbreak in the Paraná state of Brazil found a $52 \%$ prevalence of F4 in the analyzed samples (SOUZA et al., 2007). 
The K99 fimbria, currently known as F5, has a molecular weight of $18.5 \mathrm{kDa}$ and a diameter of $4.8 \mathrm{~nm}$. F5 can be found in ETEC samples in calves and swine (MOON et al., 1977). Selective medium Minca is used to induce expression of the fimbriae.

Purification and characterization of F41 was reported by De GRAAF \& ROODA (1982); this fimbria has a molecular weight of $29.5 \mathrm{kDa}$ and a diameter of $3.2 \mathrm{~nm}$. Its production can be compared with the production of F5. Use of F41 as an antigen in vaccines is less well defined when compared with the fimbriae F4, F5, and F6 (MOON, 1990). This fimbria is usually reported in bovines and swine (GAASTRA \& GRAAF, 1982). F5 and F41 can hemagglutinate human, guinea pig, and sheep erythrocytes in the presence of mannose (MOSELEY et al., 1986).

The strains most commonly found in newborn piglets have F5 (K99) and F6 (987P) fimbriae. During the first week of life, the receptors for F5 are found in enterocytes of piglets and then decrease significantly (ALFIERI et al., 2010). The 987P fimbria was analyzed by electron microscopy, showing a diameter of $7 \mathrm{~nm}$, molecular weight of $18.9 \mathrm{kDa}$, and $\mathrm{pH}$ of 3.7 (MORGAN et al., 1978). It is usually found in newborn piglets (GAASTRA \& GRAAF, 1982); however, the receptors in pigs for this fimbria are also present in young and adult animals (ALFIERI et al., 2010). Blood agar culture medium is more selective for inducing this fimbria (FRANCIS et al., 1982). Fimbria 987P does not have hemagglutinating properties (ISAACSON \& RICHTER, 1981), but attaches to glycoprotein receptors on swine enterocytes.

The F18 fimbria was expressed only in special laboratory culture conditions (WITTING et al., 1994). This fimbria has two variants, F18ab and F18ac, and their identification was analyzed by serology and polymerase chain reaction (PCR) (IMBERECHTS et al., 1994). According to CODDENS et al. (2007), F18 has the ability to colonize the intestinal epithelium, adhere to specific receptors, and cause edema disease or diarrhea after weaning.

In pig farming, fimbriae F4, F5, F6, and F41 are linked to enteric disorders, and the F18 fimbria is linked with edema disease (FAIRBROTHER et al., 1986). Edema disease is an illness that affects weaned piglets, and it is related to $\boldsymbol{E}$. coli strains linked to different virulence factors such as fimbriae and toxins (GYLES, 1992). MOON et al. (1980) reported that the impact of the fimbriae in the diagnosis and vaccination depends on the number and prevalence of antibody types, favoring intestinal colonization of occurring species.
In addition to ETEC, another class of E. coli that causes diarrhea in newborn pigs is porcine pathogenic $\boldsymbol{E}$. coli (PEPEC), which is similar to the $\boldsymbol{E}$. coli that causes enteric infections in humans and animals through the lesion type A/E (attaching and effacing) (AN et al., 1999).These lesions are characterized by close adherence to the membranes of the enterocytes and activation of a variety of chromosomal gene products that interact with components of the host cells, leading to the destruction of enterocytes and cytoskeletons edges (LEVINE, 1987).

Phenotypic and genotypic characterizations of PEPEC showed that they lack the virulence factors of ETEC but present porcine attaching and effacingassociated ( $p a a$ ) nucleotide sequences, associated with the ability to produce injury type $\mathrm{A} / \mathrm{E}$ in piglets and pig ileum sections (LECLERC et al., 2006). The $\boldsymbol{E}$. coli $\mathrm{A} / \mathrm{E}$ lesion is caused by an outer membrane protein, known as intimin, which is encoded by the eae gene and facilitates bacterial adhesion (MALIK et al., 2006).

Histopathological changes caused by $\mathrm{A} / \mathrm{E}$ injuries are indistinguishable from those produced in humans by EPEC. A/E injuries are also caused by other bacteria (including EHEC), by agents of hemorrhagic colitis, and by uremic syndrome in humans (KAPER\& O'BRIEN, 1998); EPEC also causes diarrhea specifically in rabbits (MOON et al., 1983). All genes involved in $\mathrm{A} / \mathrm{E}$ injuries are located on the locus of enterocyte effacement (LEE) chromosome.

The gene identified in paa PEPEC was cloned, and it showed strong correlation with the eae gene of EHEC O157:H7 and with isolates of dogs, rabbits, and pigs (AN et al., 2000). Characterization of e paa gene suggests its contribution to the early stages of PEPEC virulence (BATISSON et al., 2003) and its rPaa protein weights (PEREIRA et al., 2015b). In Paraná, 300 stool samples of 100 pigs from different farms were analyzed using PCR for the paa gene and its link to the enterotoxins Sta, Stb, and LT. Results were $22 \%$ positive for the paa gene, which is associated with the presence of genes for other adhesins and toxins (F4, F18, F41, Paa, Sta, Stb, and LT). This demonstrates the importance of the paa gene as a virulence factor (VIDOTTO et al., 2013). The characteristics described above are listed in table 1 .

\section{Diagnosis}

It is difficult to diagnose diarrhea caused by ETEC using clinical signs and necropsy lesions, which are considered non-specific. Because $\boldsymbol{E}$. coli are commonly present in the intestinal flora of animals, their discovery is not a conclusive diagnosis. 
Table 1 - Summary of $\boldsymbol{E}$. coli groups and their relation to different species.

\begin{tabular}{lllll}
\hline $\begin{array}{l}\text { Group of } \\
\text { E. } \text { coli }\end{array}$ & Adhesin & $\begin{array}{c}\text { Molecular } \\
\text { weight }\end{array}$ & \multicolumn{1}{c}{ Affected species } & Disease \\
\hline ETEC & F4 (K88) & $27.5 \mathrm{kDa}$ & Newborn, post-weaning, and finishing pigs & Colibacillosis \\
ETEC & F5 (K99) & $18.5 \mathrm{kDa}$ & Calves, lambs, and newborn pigs & Colibacillosis \\
ETEC & F41 & $29.5 \mathrm{kDa}$ & Cattle and piglets & Colibacillosis \\
ETEC & F6 (987) & $18.9 \mathrm{kDa}$ & Young and adult pigs & Colibacillosis \\
ETEC & F18 & $36 \mathrm{kDa}$ & Post-weaning pigs & Edema disease \\
EPEC & Paa & $28 \mathrm{kDa}$ & Pigs & Colibacillosis \\
EHEC & Intimin & $94 \mathrm{kDa}$ & Humans & Hemorrhagic Colitis and Hemolytic and Uremic Syndrome
\end{tabular}

A phenotypic or genotypic description of the isolated strain is required to recognize bacterial fimbriae and characterize the genes encoding the fimbrial proteins and enterotoxins (ALFIERI et al., 2010).

\section{Control measures}

A number of factors influence the presence of diarrhea within pig production. One of the main problems is improper disinfection of the stall and poor sanitation among the sows. A lack of adequate temperature control for the piglets and sows (the ideal temperature is $33^{\circ} \mathrm{C}$ ), and poor air circulation also play a role. Another factor is low attention by the handler to hygiene aspects, such as the use of dirty boots, which serve as a source of infection for the piglets. Additionally, diets low in digestibility can cause the substrate to remain longer in the small intestine of piglets, favoring the multiplication and prevalence of $\boldsymbol{E}$. coli. Finally, environmental conditions and the immune state of sows also influence the appearance of diarrhea (MORÉS \& MORENO, 2007).

There are several ways to minimize the damage caused by ETEC, some of which include sow vaccination before labor, autogenous vaccines in piglets, use of prophylactic antibiotics, and selection of animals lacking genes encoding receptors for fimbriae. Other methods to reduce losses due to ETEC are active immunization (intramuscular immunization with fimbriae or oral immunization with attenuated or non-virulent strains which contain fimbriae), passive immunization (oral administration of yolk immunoglobulin from eggs (IgY) against fimbriae), use of powdered plasma proteins (FAIRBROTHER et al., 2005), and intranasal vaccines in piglets to prevent diarrhea (LIN et al., 2013). Measures of control and prevention are listed in table 2.

Vaccination schedules proposed by companies that produce vaccines against colibacillosis recommend vaccination of swine matrices during pregnancy in two ways: at four and two weeks before labor in gilts, and a revaccination two weeks before labor in sows. The first contact of the mother with the vaccine should be preconized in two doses to stimulate a higher immune response. As weaned piglets are often affected by ETEC, they must be able to produce immunity through antibodies received in colostrum (ANAMI, 2008). The colostrum can be absorbed by the enterocytes in piglets up to the first 24 hours after birth, as this passive immunization is sufficient for protection by the immunoglobulin (IgG) to prevent diarrhea (JENSEN et al., 2001). The vaccination programs are listed in table 3. PEREIRA et al. (2015a) evaluated the humoral immune response of immunized sows with recombinant proteins of ETEC (F4, F5, F6,

Table 2 - Measures of control and prevention in piglets, gilts, and sows.

\begin{tabular}{ll}
\hline Age of animals & \multicolumn{1}{c}{ Measures of control and prevention } \\
\hline Piglets & $\begin{array}{l}\text { Autogenous vaccines, oral vaccine, oral immunization with immunoglobulin (IgY), plasma protein powder, } \\
\text { prophylactic antibiotics, or selection of animals that lack genes encoding the fimbrial receptors } \\
\text { Adequate temperature control, active and passive immunization, or vaccination with bacterins or recombinant } \\
\text { protein (2 doses) four and two weeks before delivery } \\
\text { Adequate temperature control, active and passive immunization, vaccination with bacterins or recombinant protein } \\
\text { Sows }\end{array}$ \\
\hline
\end{tabular}

Ciência Rural, v.46, n.8, ago, 2016. 
Table 3 - Vaccination programs according to each manufacturer.

\begin{tabular}{|c|c|c|c|}
\hline Vaccines & Dosage & Age & Manufacturer \\
\hline \multirow{4}{*}{$\begin{array}{l}\text { Porcilis }^{\circledR} \text { coli } \\
(\mathrm{LT} \text { toxoid, F4ab, } \\
\text { F4ac, F5, F6) }\end{array}$} & \multirow{4}{*}{$2 \mathrm{ml}$} & Unvaccinated gilts and sows & \\
\hline & & $6-8$ weeks before delivery $-1^{\text {st }}$ dose & \multirow{3}{*}{ MSD Animal Health } \\
\hline & & 4 weeks after the first dose & \\
\hline & & $\begin{array}{l}\text { Revaccination: a single dose in the second half of } \\
\text { pregnancy }\end{array}$ & \\
\hline \multirow{4}{*}{$\begin{array}{l}\text { Porcilis }^{\circledR} 2 * 4 * 3 \\
(\mathrm{~K} 88, \mathrm{~K} 99,987 \mathrm{P}, \mathrm{F} 41)\end{array}$} & \multirow{4}{*}{$2 \mathrm{ml}$} & Unvaccinated gilts and sows $6-8$ weeks before labor: & \multirow{4}{*}{ MSD Animal Health } \\
\hline & & $1^{\text {st }}$ dose & \\
\hline & & 4 weeks after the first dose & \\
\hline & & $\begin{array}{l}\text { Revaccination: a single dose in the second half of } \\
\text { pregnancy }\end{array}$ & \\
\hline \multirow{5}{*}{$\begin{array}{l}\text { Suiseng } \\
\text { (F4ab, F4ac, F5, F6, } \\
\text { LT) }\end{array}$} & \multirow{5}{*}{$2 \mathrm{ml}$} & Gilts & \multirow{6}{*}{ HIPRA } \\
\hline & & 70 days of gestation: $1^{\text {st }}$ dose & \\
\hline & & 90 days of gestation: $2^{\text {nd }}$ dose & \\
\hline & & Sow $90-100$ days of gestation: one dose & \\
\hline & & Gilts & \\
\hline \multirow{5}{*}{$\begin{array}{l}\text { PILI } \text { SHIELD }^{\circledR} \\
\text { PORCINO (K88, K99, } \\
\text { 987P, F41) }\end{array}$} & \multirow{5}{*}{$2 \mathrm{ml}$} & 5 weeks before delivery: $1^{\text {st }}$ dose & \\
\hline & & 2 weeks before delivery: $2^{\text {nd }}$ dose & \multirow{5}{*}{ Novartis } \\
\hline & & Sows & \\
\hline & & 2 weeks before delivery: $1^{\text {st }}$ dose & \\
\hline & & Gilts & \\
\hline \multirow{4}{*}{$\begin{array}{l}\text { SERKEL GASTRO } \\
\text { RV }^{\circledR}(\mathrm{K} 88,987 \mathrm{P}, \mathrm{K} 99, \\
\text { F41) }\end{array}$} & \multirow{4}{*}{$2 \mathrm{ml}$} & 5 weeks before delivery: $1^{\text {st }}$ dose & \\
\hline & & 2 weeks before delivery: $2^{\text {nd }}$ dose & \multirow{3}{*}{ Vencofarma } \\
\hline & & Sows & \\
\hline & & 2 weeks before delivery: $1^{\text {st }}$ dose & \\
\hline
\end{tabular}

F18, and F41), and the response was compared with a group that received a commercial vaccine containing ETEC bacterins and a control group. There was a statistically significant increase in the levels of fimbriae F4, F5, F6, and F18 antibodies in sows vaccinated with recombinant proteins compared to the control group. Furthermore, all piglets showed significantly elevated antibody levels to all fimbriae, demonstrating the transfer of antibodies via colostrum.

Studies show that the swine matrices immunized with colibacillosis vaccines are able to better protect their piglets as compared to unvaccinated ones (HUR \& LEE, 2012). The vaccine is capable of inducing the production of specific antibodies, which decrease bacterial adhesion receptors on the intestinal cells and neutralize enterotoxins. The commercial vaccines contain inactivated bacterins or purified vaccine fimbrial subunits, and some already contain enterotoxin LT; they are given via a parenteral route (ALFIERI et al., 2010). The rPaa protein could be included in the development of a vaccine against colibacillosis (PEREIRA et al., 2015b).

Commercial vaccines are not completely efficient, owing the dependence on maternal antibodies, however, the commercial vaccines administered parenterally to pregnant sows are effective against newborn diarrhea if the vaccine has all fimbrial antigens that occur on the farm, if there is sufficient intake of colostrum per animal, and if there is a low pressure of infection (HAESEBROUCK et al., 2004).

\section{CONCLUSION}

Immunization of sows with adhesins is essential for stimulating the production of antibodies and conferring these to piglets through colostrum. Vaccination may be considered an excellent strategy and quite effective when used properly, and it is considered one of the best ways to prevent diseases 
within a production system where the pressure of infection is high. At the same time, risk factors also need to be avoided through control measures; this is fundamental to ensure a healthy environment free of disease. Although, the risk of death in swine after a single infection with ETEC is not high, complex infections with ETEC, rotavirus, and coccidia are often found in piglets at both newborn and postweaning stages, leading to high economic losses for pig producers.

\section{ACKNOWLEDGEMENTS}

Research supported by the Conselho Nacional de Desenvolvimento Científico e Tecnológico (CNPq).

\section{REFERENCES}

ALFIERI, A.A. et al. (Eds.). Tópicos em sanidade e manejo de suínos. Campinas: Sanphar, Sorocaba: Curuca Consciência Ecológica, 2010. p.165-184.

ALMEIDA, F.S. et al. Diarreia suína: estudo da etiologia, virulência e resistência a antimicrobianos de agentes isolados em leitões na região de Ribeirão Preto-SP, Brasil. Ars Veterinária, v.23, n.3, p.151-157, 2007. Available from: $<$ http://dx.doi.org/10.15361/21750106.2007v23n3p151-157>. Accessed: Nov. 15, 2014.

AN, H. et al. Distribution of a novel locus called Paa (porcine attaching and effacing associated) among enteric Escherichia coli. Advances in Experimental Medicine and Biology, v.473, p.179-184, 1999. Available from: <http://www.ncbi.nlm.nih.gov/ pubmed/10659356>. Accessed: Jul. 14, 2015. doi: 10.1007/978-14615-4143-1_17.

AN, H. et al. Presence of the LEE (locus of enterocyte effacement) in pig attaching and effacing Escherichia coli and characterization of eae, espA, espB and espD genes of PEPEC (pig EPEC) strain 1390. Microbial Pathogenesis, v.28, p.291-300, 2000. Available from: <http://www.ncbi.nlm.nih.gov/pubmed/10799279>. Accessed: Nov. 15, 2014. doi: 10.1006/mpat.1999.0346.

ANAMI, R. Desenvolvimento e avaliação de uma bacterina contra Colibacilose em suínos. CESUMAR, v.10, n.02, p.135-140, 2008. Available from: <http://periodicos.unicesumar.edu.br/index.php/ iccesumar/article/view/831>. Accessed: Out. 17, 2014.

BATISSON, I. et al. Characterization of the novel factor paa involved in the early steps of the adhesion mechanism of attaching and effacing $\boldsymbol{E}$. coli. Infection and Immunology, v.71, p.45164525, 2003. Available from: <http://www.ncbi.nlm.nih.gov/ pubmed/12874331>. Accessed: Mar. 2, 2015: doi: 10.1128/ IAI.71.8.4516-4525.2003.

BLANCO, J. et al. Escherichia coli enterotoxigenicos, necrotoxigenicos y verotoxigenicos de origen humano y bovino. Patogenesis, epidemiologia y diagnostico microbiologico. Lugo, Spain: Servicio Publicaciones Diputacion Provincial de Lugo, 1993. p.1-361.

CARAMORI JÚNIOR, J.G. et al. Causas de mortalidade em leitões em granja comercial do médio-norte de Mato Grosso.
Revista Brasileira de Ciência Veterinária, v.17, n.1, p.12-15, 2010. Available from: <http://doi.editoracubo.com.br/10.4322/ rbcv.2014.136>. Accessed: Mar. 3, 2015.

CODDENS, A. et al. The age-dependent expression of the F18+ $\boldsymbol{E}$. coli receptor on porcine gut epithelial cells is positively correlated with the presence of histo-bloob group antigens. Veterinary Microbiology, v.122, p.332-341, 2007. Available from: <http:// www.ncbi.nlm.nih.gov/pubmed/17353102>. Accessed: Nov. 2, 2014. doi: 10.1016/j.vetmic.2007.02.007

DE GRAAF, F.K.; ROORDA, I. Production, purification and characterization of the fimbrial adhesive antigen F41 isolated from the calf enteropathogenic Escherichia coli strain B41 M. Infection and Immunology, v.36, p.751-753, 1982. Available from: $<$ http:// www.ncbi.nlm.nih.gov/pubmed/6123486>. Accessed: Mar. 12, 2014. doi: 0019-9567/82/050751-08\$02.00/0.

FAIRBROTHER, J.M. et al. New fimbrial antigen F165 from Escherichia coli serogroup $\mathrm{O} 115$ strains isolated from piglets with diarrhea. Infection and Immunity, v.51, n.1, p.10-15, 1986. Available from: $<$ http://www.ncbi.nlm.nih.gov/pubmed/2867041>. Accessed: Jun. 4, 2015. doi: 0019-9567/86/010010-06\$02.00/0.

FAIRBROTHER, J.M. et al. Escherichia coli in postweaning diarrhea in pigs: an update on bacterial types, pathogenesis, and prevention strategies. Animal Health Research Reviews, v.6, n.1, p.17-39, 2005. Available from: <http://www.ncbi.nlm.nih. gov/pubmed/16164007>. Accessed: Apr. 15, 2015. doi: 10.1079/ AHR2005105.

FRANCIS, D.H. et al. Production of K88, K99, and 987P antigens by Escherichia coli cultured on synthetic and complex media. Journal of Clinical Microbiology, v.15, p.181-183, 1982. Available from: <http://www.ncbi.nlm.nih.gov/pubmed/6764769>. Accessed: Jun. 23, 2013. doi: 0095-1137/82/010181-03\$02.00/0.

GAASTRA, W.; De GRAAF, F.K. Host-specific fimbrial adhesins of noninvasive enterotoxigenic Escherichia coli strains. Microbiol Reviews, v.46.p.129-161, 1982. Available from: <http://www.ncbi. nlm.nih.gov/pmc/articles/PMC281536/>. Accessed: Jul. 12, 2015. doi: 0146-0749/82/020129-33\$02.00/0.

GYLES, C.L. Escherichia coli cytotoxins and enterotoxins. Canadian Journal of Microbiology, v.38, p.734-746, 1992. Available from: $<$ http://www.ncbi.nlm.nih.gov/pubmed/1393838>. Accessed: Mar. 12, 2015. PMID: 1393838.

HAESEBROUCK, F. et al. Efficacy of vaccines against bacterial diseases in swine: what can we expect. Veterinary Microbiology, v.100, p.255-268, 2004. Available from: <http://www.ncbi.nlm.nih. gov/pubmed/15145504>. Accessed: Nov. 12, 2014. doi: 10.1016/j. vetmic.2004.03.002

HIRSH, D.C. Escherichia coli. In: HIRSH, D.C.; ZEE, Y.C. Microbiologia Veterinária. Rio de janeiro: Guanabara, 2003. p.63-68.

HUR, J.; LEE, J.H. Comparative evaluation of a vaccine candidate expressing enterotoxigenic Escherichia coli (ETEC) adhesions for colibacillosis with a commercial vaccine using a pig model. Vaccine, v.30, p.3829-3833, 2012. Available from: <http://www. ncbi.nlm.nih.gov/pubmed/22507658>. Accessed: Mar. 18, 2014. doi: 10.1016/j.vaccine.2012.03.087.

IMBERECHTS, H.et al. Sequences related to the major subunit gene fedA of F1107 fimbriae in porcine Escherichia coli strains 
that express adhesive fimbriae. FEMS Microbiology Letters, v.119, p.309-314, 1994. Available from: <http://www.ncbi.nlm. nih.gov/pubmed/1348723>. Accessed: Jul. 14, 2014. doi: 00199567/92/051963-09\$02.00/0

ISAACSON, R.E.; RICHTER, P. Escherichia coli 987P pilus: purification and partial characterization. Journal of Bacteriology, v.146, p.784-789, 1981. Available from: <http://www.ncbi.nlm. nih.gov/pmc/articles/PMC217025/>. Accessed: Mar. 12, 2014. doi: 0019-9567/92/051963-09\$02.00/0.

JENSEN, A.R. et al. Development of intestinal immunoglobulin absorption and enzyme activities in neonatal pigs is diet dependent. Journal of nutrition,v.131, p.3.259-3.265, 2001. Available from: $<$ http://www.ncbi.nlm.nih.gov/pubmed/11739877>. Accessed: Nov. 19, 2014. PMID: 11739877

KAPER, J.B.; O'BRIEN, A.D. Escherichia coli 0157:H7 and other Shiga toxin-producing $E$. coli strains. Washington: ASM, 1998. 465p.

LECLERC, S. et al. Paa originally identified in attaching and effacing $\boldsymbol{E s c h e r i c h i a ~ c o l i}$, is also associated with enterotoxigenic $\boldsymbol{E}$. coli. Research in Microbiology, v.158, p.97-104, 2006. Available from: <http://www.ncbi.nlm.nih.gov/pubmed/17125971>. Accessed: Dec. 2, 2014. doi: 10.1016/j.resmic.2006.09.004.

LEVINE, M. M. Escherichia coli that cause diarrhea: Enterotoxigenic, Enteropathogenic, Enteroinvasive, Enterohemorrhagic, and Enteroadherent. Journal of infeccions Diseases, v.155, n.3, p.377-389, 1987. Available from: <http:// www.ncbi.nlm.nih.gov/pubmed/3543152>. Accessed: Mar. 22, 2014. doi: 10.1093/infdis/155.3.377.

LIN, J. et al. Protection of piglets against enteric colibacillosis by intranasal immunization with K88ac (F4ac) fimbriae and heat labile enterotoxin of Escherichia coli. Veterinary Microbiology, v.162, p.731-739, 2013. Available from: <http://www.ncbi.nlm.nih. gov/pubmed/23089483>. Accessed: Oct. 16, 2015. doi: 10.1016/j. vetmic.2012.09.025

LIU, W. et al. Frequency of virulence factors in Escherichia coli isolated from suckling pigs with diarrhoea in China. Veterinary Journal, v.199, p.286-289, 2014. Available from: <http://www. sciencedirect.com/science/article/pii/S1090023313006114>. Accessed: Feb. 24, 2015. doi: 10.1016/j.tvj1.2013.11.019.

MALIK, A. et al. Serotypes and intimin types of intestinal and faecal strains of eae+ Escherichia coli from weaned pigs. Veterinary Microbiology, v.114, p.82-93, 2006. Available from $<$ http://www.ncbi.nlm.nih.gov/pubmed/16326041>. Accessed: Mar. 3, 2015. doi: 10.1016/j.vetmic.2005.11.044.

MELKEBEEK V. et al. ETEC vaccination in pigs. Veterinary Immunology and Immunopathology, v.152, p.37-42, 2013. Available from: $<$ http://www.sciencedirect.com/science/article/pii/ S0165242712003546>. Accessed: Nov. 10, 2014. doi: 10.1016/j. vetimm.2012.09.024.

MENIN, A. et al. Enteropathogenic bacterial agents in pigs of different age groups and profile of resistance in strains of Escherichia coli and Salmonella spp. to antimicrobial agents. Ciência Rural, v.38, p.1687-1693, 2008. Available from: $<$ http://dx.doi.org/10.1590/S0103-84782008000600030>. Accessed: Nov. 10, 2013.
MOON, H.W. et al. Occurrence of K99 antigen on Escherichia coli isolated from pigs and colonization of pig ileum by $\mathrm{K}^{+} 9^{+}$ enterotoxigenic $\boldsymbol{E}$. coli from calves and pigs. Infection and Immunology, v.15, n.2, p.614-620, 1977. Available from: <http:// www.ncbi.nlm.nih.gov/pubmed/321356>. Accessed: Aug. 7, 2015. PMC321356.

MOON, H.W. et al. Prevalence of pilus antigens, enterotoxin types, and enteropathogenicity among K88-Negative Enterotoxigenic Escherichia coli from neonatal pigs. Infection and Immunity, v.27, n.1, p.222-230, 1980. Available from: <http://www.ncbi.nlm.nih. gov/pubmed/6102079>. Accessed: Aug. 15, 2015. PMC6102079.

MOON, H.W. et al. Attaching and effacing activities of rabbit and human enteropathogenic Escherichia coli in pig and rabbit intestines. Infection and Immunity, v.41, n.3, p.1340-1351, 1983. Available from: $<$ http://www.ncbi.nlm.nih.gov/pubmed/6350186>. Accessed: Aug. 01, 2015. PMC365769.

MORÉS, N.; MORENO, A.M. Colibacilose neonatal.In: SOBESTIANSKY, J.; BARCELLO, D.E.S.N. (Eds). Doenças dos suínos. 2.ed. Goiânia: Cânone editorial. 2007.p.71-76.

MORGAN, R.L. et al. Immunization of suckling pigs against enterotoxigenic Escherichia coli-induced diarrheal disease by vaccinatingdams with purified 987 or K99 Pili: protection correlates with pilus homology of vaccine and challenge. Infeccion and Immunity,v.33, n.3, p.771-777, 1978. Available from: $<$ http:// www.ncbi.nlm.nih.gov/pubmed/365769>. Accessed: Aug. 20, 2015. PMC365769.

MOSELEY, S.L. et al. Cloning of chromosomal DNA encoding the F41 adhesin of enterotoxigenic Escherichia coli and genetic homology between adhesins F41 and K88. Journal of Bacteriology, v.167, p.799-804, 1986. Available from: <http:// www.ncbi.nlm.nih.gov/pubmed/2875061>. Accessed: Aug. 19, 2015. PMC2875061.

NAGY, B.; FEKETE, P.Z.S. Enterotoxigenic Escherichia coli (ETEC) in farm animals. Veterinary Research, v.30, p.259284, 1999. Available from: <http://www.ncbi.nlm.nih.gov/ pubmed/10367358>. Accessed: Aug. 05, 2015. PMC10367358.

ORSKOV,I.etal.Simultaneous occurrence of $\boldsymbol{E}$. coliB and Lantigens in strains from diseased swine. Acta Pathologica Microbiologica Scandinava, v.53, p.404-422, 1961. Available from: <http:// onlinelibrary.wiley.com/doi/10.1111/j.1699-0463.1961.tb00424.x/ abstract $>$. Accessed: Jul. 13, 2015. doi: 10.1111/j.1699-0463.1961. tb00424.x.

ORSKOV, I. et al. Serology, chemistry, and genetics of O and K antigens of Escherichia coli. Bacteriology reviews, v.41, n.3, p.667-710, 1977. Available from: <http://www.ncbi.nlm.nih.gov/ pmc/articles/PMC414020/>. Accessed: Aug. 5, 2015. PMC411020.

PEREIRA, D.A. et al. Humoral immune response of immunized sows with recombinant proteins of enterotoxigenic Escherichia coli. World Journal of Vaccines, v.5, p.60-68, 2015a. Available from: <file://D:/Perfil/Downloads/WJV 2015021013310836. pdf $>$. Accessed: Aug. 11, 2015. doi: 10.4236/wjv.2015.51008.

PEREIRA, D.A. et al. Cloning and expression of the porcine attaching and effacing-associated (paa) gene of enteropathogenic Escherichia coli. Genetic and Molecular Research, v.14, n.3, p.8574-8580, 2015b. Available from: 
<http://www.ncbi.nlm.nih.gov/pubmed/26345788>. Accessed: Aug. 15, 2015. doi: 10.4238/2015.

RUTTER, J.M.; JONES, G.W. Protection against enteric disease caused by Escherichia coli a model for vaccination with a virulence determinant? Nature, v.2, p.242-531, 1973. Available from: $<$ http:// www.nature.com/nature/journal/v242/n5399/abs/242531a0.html>. Accessed: Jul. 18, 2015. doi:10.1038/242531a0.

SOUZA, C. et al. Caracterização sorológica dos antígenos de superfície em cepas de Escherichia coli isoladas de suínos com diarreia no estado do Paraná. Archives of Veterinary Science, v.12, n.3, p.51-55, 2007. Available from: <http://ojs.c3sl.ufpr.br/ ojs/index.php/veterinary/article/viewFile/10927/7385>. Accessed: Jul. 1, 2015.

TRABULSI, L.R.; ALTERTHUM, F. Microbiologia. 4.ed. São Paulo, Atheneu. 2005. 894p.

TRABULSI, L.R. et al. Typical and atypical enteropathogenic Escherichia coli. Emerging Infection Disesase Journal, v.8, p.508-513, 2002. Available from: <http://www.ncbi.nlm.nih. gov/pmc/articles/PMC2732489/>. Accessed: Aug. 01, 2015. doi: 10.3201/eid0805.010385.

VIDOTTO, M.C. et al. Prevalence of virulence genes in Escherichia coli isolated from piglets with diarrhea in the Paraná, South Brazil. Brazilian Journal of Microbiology, v.44, n.2, p.515-517, 2009.
Available from: <http://www.scielo.br/scielo.php?script=sci_artt ext\&pid=S1517-83822009000100035>. Accessed: Jul. 30, 2015. doi: 10.1590/S1517-83822009000100035.

VIDOTTO, M.C. et al. Prevalence of the Paa gene (porcine attaching and effacing associated) in porcine enteropathogenic Escherichia coli (PEPEC) associated with postweaning diarrhea in south Brazil. Brazilian Journal of Microbiology, v.44, n.2, p.515-517, 2013. Available from: <http://www.scielo.br/scielo. php? script $=$ sci_arttext\&pid $=$ S 1517-83822013000200030 $>$. Accessed: Jul. 2, 2015. doi: 10.1590/S1517-83822013000200030.

WILLS, R.W. Diarrhea in growing-finishing swine. Veterinary Clinics of North America: Food Animal Practice, v.16, n.1, p.175-185, 2000. Available from: <http://www.sciencedirect.com/ science/article/pii/S0749072015301407>. Accessed: Aug. 1, 2015. doi: 10.1016/S0749-0720(15)30140-7.

WITTING, W. et al. Expression and plasmid transfer of genes coding for fimbrial antigen F107 in porcine Escherichia coli strains. Zentralbl Bakteriology, v.281, p.130-139, 1994. Available from: $<$ http://www.sciencedirect.com/science/article/pii/ S0934884011805633>. Accessed: Aug. 19, 2015.

ZLOTOWSKI, P. et al. Patogenia da diarreia dos suínos: modelos e exemplos. Acta Scientiae Veterinariea, v.36, n.1, p.81-8, 2008. Available from: <http://www.ufrgs.br/actavet/36-suple-1/11_ patogenia.pdf $>$. Accessed: Jun. 20, 2015. 